\title{
A STUDY OF HYDROPONIC MELON CULTIVATIONS WITH SEVERAL SUBSTRATE MEDIA AND VARIETIES
}

\author{
Julieta Christy $^{1 *}$, Lollie Agustina P. Putri ${ }^{2}$, Diana Sofia Hanafiah ${ }^{2}$ \\ ${ }^{1}$ Post Graduate of Agrotechnology Department, Agriculture Faculty, University of North Sumatra, Medan, \\ Indonesia \\ ${ }^{2}$ Agrotechnology Department, Agriculture Faculty, University of North Sumatra, Medan, Indonesia \\ *Corresponding Author: julieta2207@gmail.com
}

\begin{abstract}
Melon is a fruit plant that has a high nutritional value. A limited agricultural land encourages the application of alternatives planting method and utilizes local materials around the community as potential planting media towards resulting a high-yielding variety. One of the cultivation techniques is the use of the hydroponics system. The objective of this study is to determine the most suitable planting medium for melon varieties to be planted hydroponically. This research was conducted in the greenhouse at the sub-district of Medan Tuntungan in the city of Medan during May to August 2017. This research used Randomize Complete Block Design Factorial with 3 replications. The use of planting media consisted of charcoal husk, cocopeat, sawdust and sand; whereby the treatment of varieties consisted of Aramis F1, Amanta F1 and Red Aroma. The results showed that the best medium for hydroponics melon is charcoal husk highlighting significant result onto the plant height, number of leaves and fruit weight of crops, from the use of charcoal husk media.
\end{abstract}

Keywords: hydroponic, soilless culture, melon, medium and variety

\section{INTRODUCTION}

Melon is a fruit plant that has a high nutritional value. The nutrient content in $236 \mathrm{~g}$ edible part of melon fruit is 78 calories, $28 \mathrm{mg}$ sodium, $593 \mathrm{mg}$ potassium, $25 \mathrm{~g}$ of carbohydrate, $2 \mathrm{~g}$ fiber, $21 \mathrm{~g}$ sugar, $90 \mathrm{mg}$ vitamin $\mathrm{C}, 4 \mathrm{mg}$ calcium, $10 \mathrm{mg}$ of iron. Lester (1997) In addition, melon fruit contains anticoagulants called adenosine so as to stop the clumping of blood cells that can lead to stroke or heart disease and carotenoid content high in melon fruit can prevent cancer and reduce the risk of lung cancer. Bangun (2004) Melon is also one of the fruit commodities that get attention to be developed in Indonesia. The national production of melon commodity in 2010 was 85,161 tons, increasing every year and becoming 150,347 tons in 2014 (Kementerian Pertanian, 2016).

Utilization of resources in the surrounding environment for the cultivation of melon plants can provide economic and nutritional improvement of the community. With the issue of land encourages the application of alternatives planting methods and utilizes local materials around the community as potential planting media to produce a highyielding variety. One of the cultivation techniques is the use of the hydroponics system. Hydroponic systems with an aggregate culture are also called substrate systems. The substrate system is a hydroponic system that uses planting media to assist plant growth (Suryani, 2015). From a variety of media that can be used as hydroponic substrate, it is necessary to select media that can provide good growth for melon plants.

Varieties are an important technological component in increasing the value of a horticultural product to obtain a good crop of growth and production. Therefore, it is necessary to study the varieties of melon plants that have good production. The objective of this study is to determine the most suitable planting medium and variety of melon to be planted hydroponically.

\section{MATERIAL AND METHOD}

This research was conducted in the greenhouse at the sub-district of Medan Tuntungan in the city of Medan during May to August 2017. This research used Factorial Randomize Block Design with 3 replications. The first factor is planting media, consisted of: (charcoal husk (M1), cocopeat (M2), sawdust (M3) and sand (4); whereby the second factor is treatment of varieties consisted of: Aramis F1 (V1), Amanta F1 (V2) and Red Aroma (V3).

Seedling medium used is charcoal husk. The nutrient used is from ABmix "Ijo Hydro" fertilizer consisting of A stock fertilizer and stock fertilizer $\mathrm{B}$. The stock Fertilizer A contains $\mathrm{KNO}_{3}, \mathrm{Ca}\left(\mathrm{NO}_{3}\right)_{2}$ and FeEDTA and the stock B fertilizer contains $\mathrm{KNO}_{3}, \mathrm{~K}_{2} \mathrm{SO}_{4}, \mathrm{KH}_{2} \mathrm{PO}_{4}, \mathrm{MgSO}_{4}, \mathrm{MnSO}_{4}, \mathrm{uSO}$, $\left(\mathrm{NH}_{4}\right) \mathrm{SO}_{4}, \mathrm{Na}_{2} \mathrm{HBO}_{3}, \mathrm{ZnSO}_{4}$, and $\mathrm{NaMoO}_{4}$ (Pradana et al., 2012). The $\mathrm{pH}$ of nutrient solution was about 6.5 dan the EC was about 800-1200 ppm. Pesticides used include Furadan 3G Biagro 60 EC, Decis 25 EC Kanon 400 EC, and Antracol 70 WP. 
Volume of fertigation were $100 \mathrm{ml} 4$ times a day (1 WAT), $100 \mathrm{ml} 5$ times a day (2-3 WAT), $150 \mathrm{ml} 5$ times a day (4 WAT) $200 \mathrm{ml} 4$ times a day (5 WAT), $250 \mathrm{ml} 4$ times a day (6 WAT), $300 \mathrm{ml} 4$ times a day ( 7-8 WAT), $200 \mathrm{ml}$ 4 times a day (9 - 12 WAT) (Pradana et al., 2012).

The observed variables were plant height $(\mathrm{cm})$, number of leaves, and weight of fruit $(\mathrm{g})$. The data were analyzed statistically using F-test and then following by Duncan Multiple Range Test at $5 \%$ level.

\section{RESULTS AND DISCUSS}

\subsection{Plant Height}

Observation of plant growth starts from 1 week to 5 weeks after transplanting (WAT). The results of observation and DMRT can be seen in Table 1. The treatment of planting media showed a significant difference when the plants were aged 2 to 5 WAT. Treatment of varieties showed a marked difference when the plants were 1 week, 2 weeks, 4 weeks and 5 weeks. The interaction treatment did not show any significant difference. The treatment of planting media and varieties showed good plant growth. This means the plant is able to grow despite the high temperature conditions in the greenhouse.

Table 1. Plant height on hydroponic media and melon varieties

\begin{tabular}{|c|c|c|c|c|c|}
\hline \multirow{2}{*}{ Treatments } & \multicolumn{5}{|c|}{ Week after Transplanting } \\
\hline & 1 & 2 & 3 & 4 & 5 \\
\hline Planting media $(\mathrm{M})$ & \multicolumn{5}{|c|}{.................... } \\
\hline Charcoal husk (M1) & 3.76 & $8.17 \mathrm{c}$ & $33.99 \mathrm{c}$ & $98.13 \mathrm{~b}$ & $119.76 \mathrm{~b}$ \\
\hline Cocopeat (M2) & 4.19 & $15.31 \mathrm{~b}$ & $47.49 \mathrm{~b}$ & $102.54 \mathrm{~b}$ & $125.14 \mathrm{ab}$ \\
\hline Sawdust (M3) & 4.18 & $9.54 \mathrm{c}$ & $36.66 \mathrm{c}$ & $86.28 \mathrm{c}$ & $103.24 \mathrm{c}$ \\
\hline Sand (M4) & 4.10 & $18.98 \mathrm{a}$ & $60.00 \mathrm{a}$ & $118.17 \mathrm{a}$ & $135.67 \mathrm{a}$ \\
\hline Varieties (V) & \multicolumn{5}{|c|}{.........cm........ } \\
\hline Aramis F1 (V1) & $4.90 \mathrm{a}$ & $15.46 \mathrm{a}$ & 46.62 & $102.81 \mathrm{~b}$ & 123.59 \\
\hline Amanta F1 (V2) & $3.73 \mathrm{~b}$ & $11.61 \mathrm{~b}$ & 41.33 & $92.31 \mathrm{~b}$ & 112.05 \\
\hline Red Aroma (V3) & $3.54 \mathrm{~b}$ & $11.93 \mathrm{~b}$ & 45.66 & $108.73 \mathrm{a}$ & 127.21 \\
\hline Interaction & $n s$ & $n s$ & $n s$ & $N s$ & $n s$ \\
\hline
\end{tabular}

Notes: The numbers followed by the same letter on the same column is not different significant according to Duncan Multiple Range Test at 5\% level; (ns) = not significant
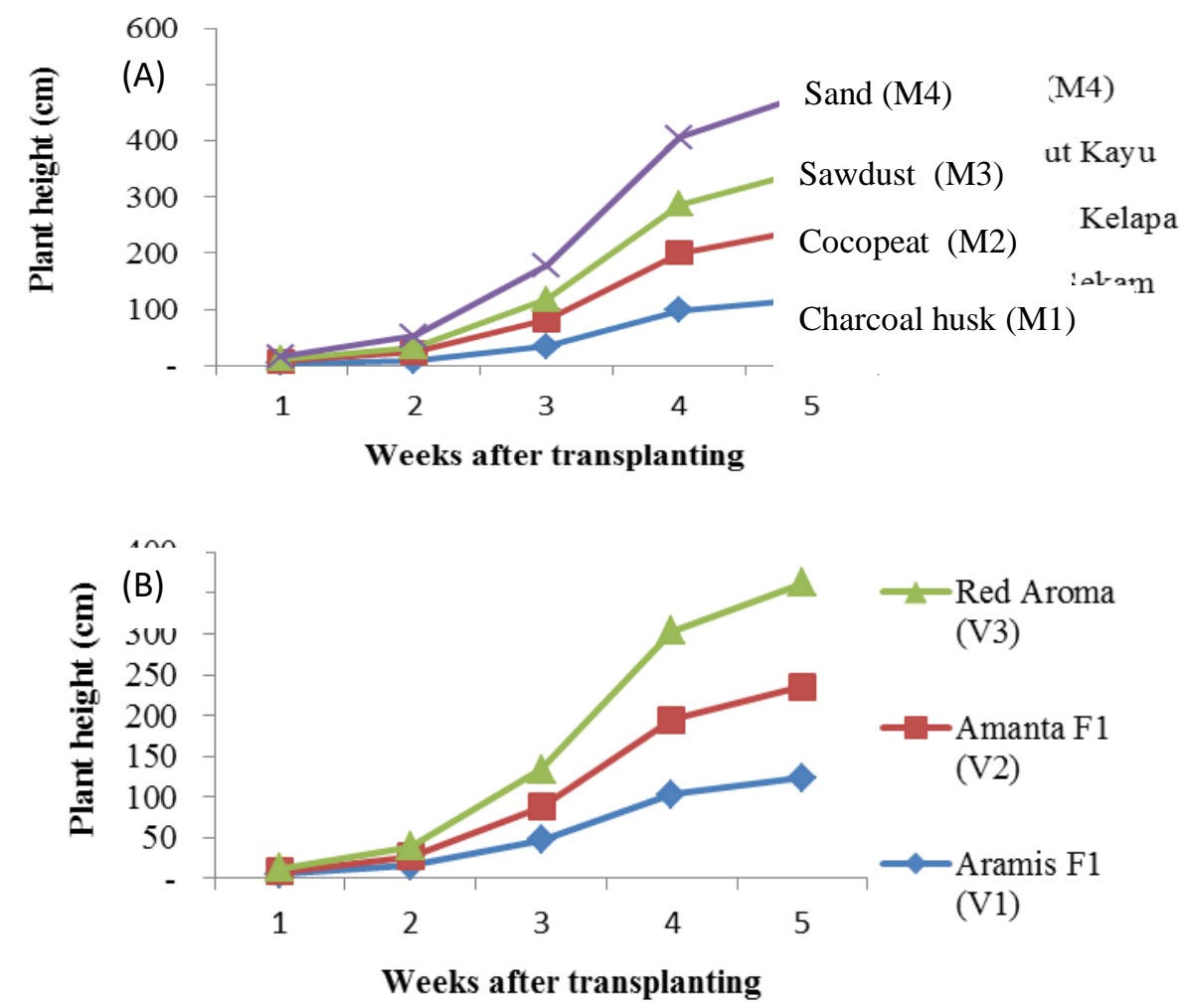

Figure 1. The height of plants in various types of planting media (A) and plant height on three varieties of plants (B) 
According to Figure 1 (A) and 1 (B) it shows that the growth of plant height increases drastically when the plant reaches the age of 2 WAT. The treatment of planting medium at 2 WAT showing the plant height significantly different from other planting mediums was shown by sand medium as well as when the plant had reached the age of 5 weeks after transplanting although the height of the plant in the treatment between sand medium and did not differ significantly.

Aramis F1 varieties showed a significantly different plant height increase with other varieties at 2 weeks after transplanting. However, by the time the plant reaches the age of 5 the plant height WAT is not significantly different in each of the tested varieties.

\subsection{Number of Leaves}

Obervation of number of leaves is described on the Tabel 2 below. Plant height is followed by an increase in the number of leaves. The increase in the number of leaves indicates that growth may occur. The results of the observation and F-test can be seen in Table 2.

Table 2. Number of melon leaves on various types of planting media and three melon varieties

\begin{tabular}{|c|c|c|c|c|c|c|}
\hline \multirow{2}{*}{ Treatment } & \multicolumn{5}{|c|}{ Weeks After Transplanting (WAT) } & \multirow[b]{2}{*}{6} \\
\hline & 1 & 2 & 3 & 4 & 5 & \\
\hline Planting Media (M) & \multicolumn{5}{|c|}{........strands......... } & \\
\hline Charcoal husk (M1) & $2.78 \mathrm{~b}$ & $6.93 \mathrm{c}$ & $19.52 \mathrm{c}$ & $22.81 \mathrm{~b}$ & $37.70 \mathrm{a}$ & 45.48 \\
\hline Cocopeat (M2) & $3.07 \mathrm{ab}$ & $9.96 \mathrm{~b}$ & $24.74 \mathrm{~b}$ & $22.93 \mathrm{~b}$ & $34.89 \mathrm{ab}$ & 43.11 \\
\hline Sawdust (M3) & $2.63 \mathrm{~b}$ & $7.41 \mathrm{c}$ & $20.07 \mathrm{c}$ & $19.89 \mathrm{c}$ & $29.59 \mathrm{~b}$ & 35.89 \\
\hline Sand (M4) & $3.33 \mathrm{a}$ & $12.15 \mathrm{a}$ & $29.89 \mathrm{a}$ & $24.37 \mathrm{a}$ & $38.44 \mathrm{a}$ & 43.96 \\
\hline Varieties (V) & \multicolumn{5}{|c|}{$\ldots \ldots \ldots$ strands ........ } & \\
\hline Aramis F1 (V1) & 2.97 & 9.86 & $24.14 \mathrm{a}$ & 22.94 & $36.61 \mathrm{a}$ & 43.31 \\
\hline Amanta F1 (V2) & 2.78 & 8.58 & $21.00 \mathrm{~b}$ & 21.06 & $30.64 \mathrm{~b}$ & 36.31 \\
\hline Red Aroma (V3) & 3.11 & 8.89 & $25.53 \mathrm{a}$ & 23.50 & $38.22 \mathrm{a}$ & 46.72 \\
\hline Interaksi & Ns & ns & ns & Ns & ns & Ns \\
\hline
\end{tabular}

Note: The numbers followed by the same letter on the same row or column is not different significant according to Duncan Multiple Range Test at_5\% level

The treatment of planting media showed a marked difference at the time of the plants aged 1 WAT to 5 WAT. Treatment of varieties showed a marked difference when plants aged 3 WAT to 5 WAT while the interaction treatment between planting medium and variety did not show any significant difference.

The treatment of planting medium at age 1 WAT of leaf number was different. The highest number of leaf was found in the treatment of sand media and cocopeat while at the age of 6 WAT the number of leaves did not show any significant difference.

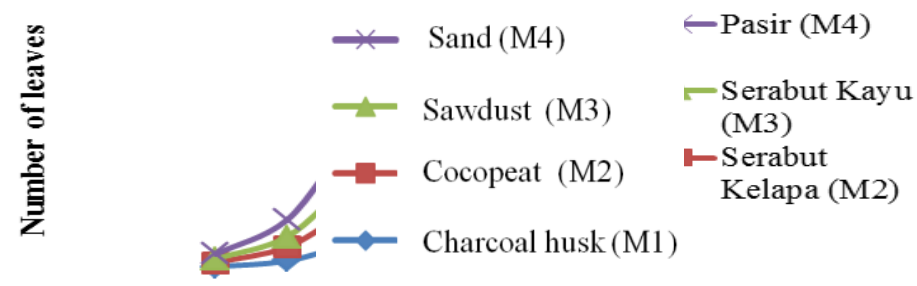

Weeks AfterTransplanting (WAT)

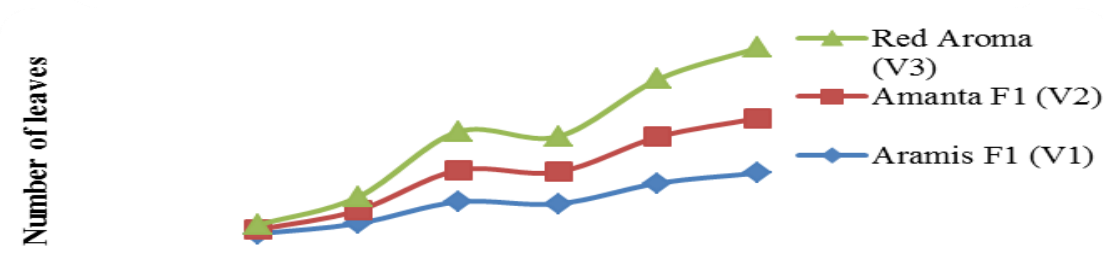

Weeks After Transplanting (WAT)

Figure 2.Addition of leaf number on giving planting media type (A) and addition of leaf number of three melon varieties (B) 
Treatment of varieties at plant age 6 MSPT also did not show any significant difference. Based on Figures 2 (A) and (B) it can be seen that at the time the plants were at the age of 3 WAT to 4 WAT the number of leaves appeared to be more static compared to the addition of the number of leaves when the plants were at ages 1 to 2 WAT and 5 to 6 WAT.

Red Aroma varieties decreased in the number of leaves from the original leaf number of 25.53 at the time 3 WAT decreased to 23.50 at 4 MSPT. The same thing also happened in the treatment of Aramis F1 Variety which also decreased the number of leaves which originally had 24.14 when 3 WAT decreased to 22.94 when 4 WAT. This decrease was due to pruning activities for plant maintenance.

Plant growth analysis is useful for a better understanding of crop development that can affect crop yields. By knowing the pattern of plant growth, volume and size growth of the cell will be able to provide an explanation of the components of the crop (Salisburry et al., 1992).

Plant growth response was measured by observation of plant height variables and number of leaves. Plant height and number of leaves showed significant differences in the treatment of planting medium and the use of several types of melon varieties. This suggests that the use of different planting media and different varieties will show different responses to vegetative growth. The results showed that the use of sand media and cocopeat in general have a significant effect on plant height and number of leaves. This can be caused by the ability of planting media to absorb nutrients given through the application of nutrient solution. Cocopeat and charcoal husk has a higher cation exchange capacity and higher total porosity than charcoal husk so it can absorb and retain nutrients (Indrawati et al., 2012).

Vegetative growth of plants also showed a significant difference in variety treatment. In general, Red Aroma varieties showed higher plant response and better leaf count compared to Aramis F1 and Amanta Varieties. Differences of varieties indicate a genetic difference. This proves that the height of the plant, the addition of the number of leaves are also influenced by genetic factors. One of the functions of nitrogen is for vegetative growth where the nitrogen element plays a role in building new plant cells which are the basic ingredients of amino acid formation (Damanik et al., 2010).

Graph of plant growth is needed to know the pattern of plant growth. The growth pattern follows the sigmoid curve so plant growth was normal. The sigmoid growth curve is a typical pattern exhibited by a plant (Gardner et al., 1991). Red Aroma varieties showed a reduction in the number of leaves from the original leaf number of 25.53 at the time 3 WAT decreased to 23.50 at 4 WAT. The same thing also happened in the treatment of Aramis F1 Variety which also decreased the number of leaves which originally had 24.14 at 3 WAT decreased to 22.94 at 4 WAT. This decrease is due to pruning activities for plant maintenance. pruning aims to encourage strong and healthy branch growth, reduce transpiration and maximize the percentage of flowering branches (Poerwanto et al., 2013).

\subsection{The weight of fruit per crop}

Observation of fruit weight per crop was done to see how big the results obtained by each plant. The average of fruit weight of cropping can be seen in Table 3. Media treatment showed significant difference, but the treatment of varieties and interaction between planting medium and variety did not show any significant difference.

Table 3. Weights of fruit per crop (g) on various types of planting media and three varieties of melon

\begin{tabular}{lcccc}
\hline \multicolumn{1}{c}{ Treatment } & \multicolumn{3}{c}{ Varieties } & Average \\
\cline { 1 - 4 } Planting Media (M) & Aramis F1 (V1) & Amanta F1 (V2) & Red Aroma (V3) & $760.23 \mathrm{a}$ \\
\cline { 1 - 4 } Charcoal husk (M1) & 756.11 & 752.92 & 771.67 & $458.14 \mathrm{~b}$ \\
Cocopeat (M2) & 548.33 & 358.58 & 467.50 & $439.27 \mathrm{~b}$ \\
Sawdust (M3) & 546.47 & 405.01 & 366.33 & $635.75 \mathrm{ab}$ \\
Sand (M4) & 577.39 & 680.00 & 649.86 & 563.84 \\
\hline Average & 607.08 & 549.13 & & \\
\hline
\end{tabular}

Treatment of varieties did not show any significant difference means that the varieties Aramis F1, Amanta F1 and Red Aroma produce the same fruit weight. The interaction treatment also did not show any significant difference so that it can be said that the Aramis F1, Amanta F1 and Red Aroma varieties if grown on charcoal husk medium, cocopeat, sawdust and sand will produce the same fruit weight per crop. 


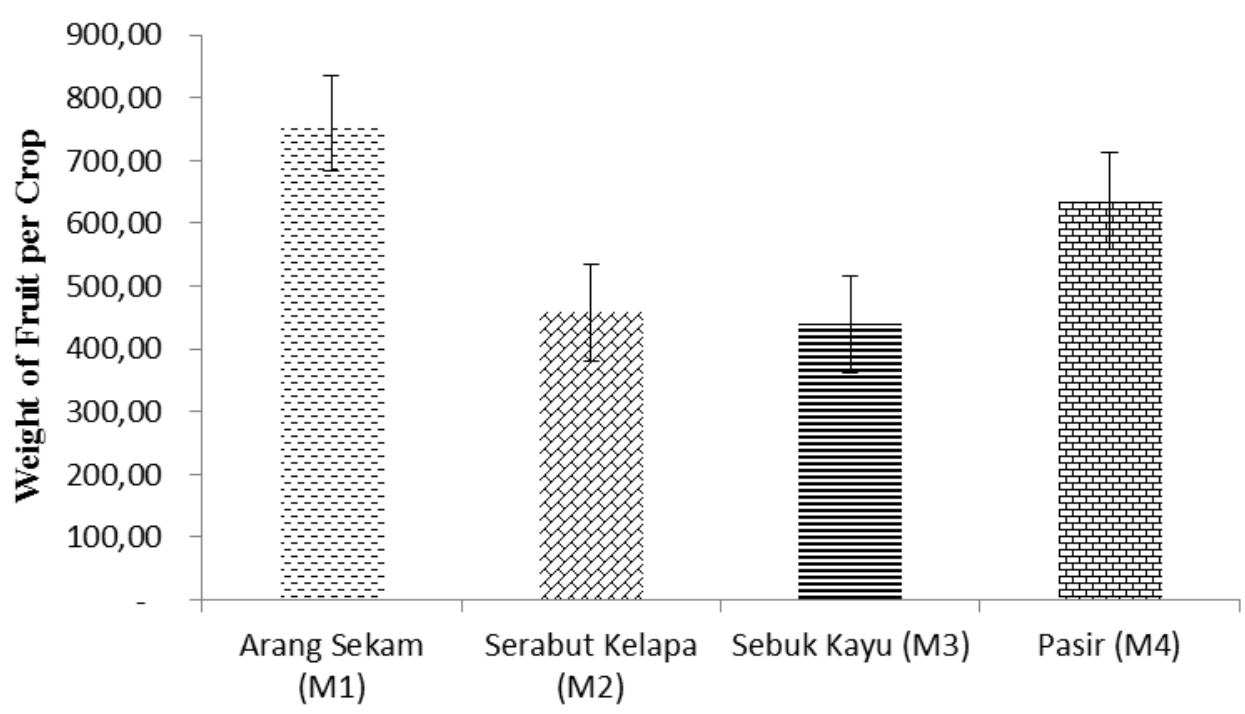

Plant Media

Figure 3. The weight of fruit per crop on the type of planting media and the weight of fruit per crop on three varieties of melon $(B)$

Based on the results of F test can be seen in Figure 3, known that the highest average fruit weight was in the media treatment of charcoal husk and sand media. Both types of media can show the highest fruit yields when compared with cocopeat and sawdust.

Development and differentiation process of plant is determined by the excess of photosynthesis (Gardner et al., 1991). The product of assimilation is a description of the result of photosynthesis of plants. If the assimilation results in sufficient condition, then it will support the formation of flowers and fruit plants. The production of a plant is a resultant of the process of photosynthesis, decreasing the assimilate due to respiration and translocation can affect the results (Jumin, 2014). The content of phosphorus is very necessary plants in the process of forming flowers and fruit

\section{CONCLUSIONS}

The results showed that the best medium for hydroponics melon is charcoal husk highlighting significant result onto the plant height, number of leaves and fruit weight of crops, from the use of charcoal husk media.

\section{REFERENCE}

Lester, G. 1997. Melon (Cucumis melo L.) fruit nutritional quality and health functionality. Hortechnology 7 (3): 222-227.

Bangun, A.P. 2004. Menangkal Penyakit dengan Jus Buah dan Sayuran (Ed. Revisi). AgroMedia. Jakarta.

Kementerian Pertanian. 2016. Basis Data Statistik Pertanian. https://aplikasi.pertanian.go.id/bdsp/hasil_ind.asp. [1 Juli 2016]

Suryani, R. 2015. Hidroponik Budi Daya Tanaman tanpa Tanah. Arcitra. Yogyakarta. 191hal.

A. W. Pradana and A. D. Susila. 2012. Penentuan Varietas Dan Media Tanam Terbaik Pada Budidaya Melon (Cucumis Melo L.) Menggunakan Teknologi Hidroponik. Skripsi. Institut Pertanian Bogor.

Salisburry, F.B. dan Ross, C.W. 1992. Fisiologi Tumbuhan. Perkembangan Tumbuhan dan Fisiologi Tumbuhan. Jilid Tiga. Penerbit ITB. Bandung.

Indrawati, R., D. Indradewa, S. N. H. Utami. 2012. Pengaruh komposisi media dan kadar nutrisi hidroponik terhadap pertumbuhan dan hasil tomat (Lycopersicon esculentum Mill.). Vegetalika Vol 1 No.3.

Damanik, M.M.B., Bachtiar, E.H., Fauzi, Sarifuddiun, dan Hamidah, H. 2010. Kesuburan Tanah dan Pemupukan. USU Press. Medan

Gardner, F.P., Pearcem R.B. dan Mitchell, R.L. 1991. Fisiologi Tanaman Budidaya. UI Press. Jakarta

R. Poerwanto and A. D. Susila. 2013. Teknologi Hortikultura. IPB Press. Bogor.

Jumin, H.B. 2014. Dasar-Dasar Agronomi. Edisi Revisi. Rajawali Press. Jakarta. 